\title{
CORRELATION BETWEEN READING HABIT AND WRITING SKILL OF THE EIGHTH GRADERS AT SMP NEGERI 6 KAYUAGUNG
}

\author{
By: \\ Riska Yohana \\ English Language Education Study Program at FKIP Islamic University of Ogan Komering Ilir \\ Kayuagung, South Sumatera \\ riskayohana1999@gmail.com \\ Dewi Sartika \\ English Language Education Study Program at FKIP Islamic University of Ogan Komering Ilir \\ Kayuagung, South Sumatera \\ dewisartika@uniski.ac.id

\section{Rekha Asmara} \\ English Language Education Study Program at FKIP Islamic University of Ogan Komering Ilir \\ Kayuagung, South Sumatera \\ rekha.asmara@gmail.com
}

\begin{abstract}
Many researches have shown the facts that the students' skills in writing can be improved by having a good reading habit. It was convinced that the students reading habit has great impact on the improvement of students' writing ability. The students who read extensively will acquire more vocabularies that lead them to have greater proficiency in writing. Therefore, this study was purposed to know whether reading habit of the eighth graders of SMPN 6 Kayuagung was significantly correlated to their writing skill. By means of Purposive sampling, 124 students of the whole number of the population were selected as the sample. A correlational study was applied. A questionnaire and written test were distributed to get the data. Twenty items of a ready-made questionnaire were used to know students' habit in reading and a writing test was administered to measure students' writing skill. The writing test was reliable because its reliability coefficient was 0.942. In data analysis, Pearson Product Moment Correlation coefficient on SPSS 20 was used. The findings revealed that r-obtained (0.685) was bigger than the value of r-table $(0.176)$ at p-value which was less than 0.05 . Thus, the formulated hypotheses were proved. In other words, there was a significant correlation between reading habit and writing skill of the eighth graders at SMPN 6 Kayuagung.
\end{abstract}

Keywords: reading habit, writing skill, correlation

\section{INTRODUCTION}

In Indonesian curriculum, the four

skills of English language regarded as the basis of communication, are fostered to master. One consideration in choosing English as a compulsory subject in school is English as a means of 
international communication and is the most commonly used language in the sciences (Adi, Padmadewi, and Ratmaningsih, 2017). It can be said that English is well-known as the language of science so that students must learn English to understand what is said by speakers and what is written in the English language version.

Based on Curriculum 2013 of junior high school, students are instructed to learn some written English texts including descriptive text. Descriptive text is a kind of genre text that contains describing people, places, or things (Muis Zainil, and Radjab, 2013,p.43). Description of the objects should be described in details through words. As Hariyadi, Wennyta, and Fitri (2018, p.41) state that description in writing is the process of creating a visual image and sensory impression through words. It infered that the objects should be described based on the real condition in order to enable the readers in gaining vivid information about what is described in the text.

To understand written English appropriately, learners should be accustomed to reading comprehensively. Thus, the learners need to do much reading as their routines. When reading has been routines for the learners, it will be beneficial for them to have good comprehension acquired during their selfexperience. Muhyidin (2020, p.2) states that reading habit is repetitive activities in reading and the pleasure obtained from carrying out the act. This is seen from the number of the reading, the time provided, and the material read. Chettri and Rout, (2013, p.14) also believed that reading habit will lead to an improved learning ability. In addition, Palani (2012, p. 1 ) claim reading habit as a crucial and important aspect to create a comprehension. It can be understood that reading habit can lead someone to have a good understanding.

Besides, reading habit has an effect to develop students' ability in learning writing. As Krashen (2016, p.115) states that learning to write is not learned from writing, but rather by reading. It indicates that reading a lot makes students be able to share many information while writing. (Linda, 2018, p.210) also views that writing is the act of transmitting knowledge in print, therefore, students must have information to share before they write. It means that reading before writing is potential to create a good product of writing. The information obtained from reading can broaden and add more ideas for writing. These ideas are then expressed and shared in the written form of language. As 
much as possible, the information should be received and processed by the writer before producing writing. This assumption is in line with Kellogg (2018) that writing is a major cognitive challenge because it is at once a test of memory, language, and thinking ability. In short, writing is the result of getting some information from reading any sources.

Furthermore, (Miller, McCardle, and Long, 2012, p.1) simplify the consideration of reading and writing connection by defining reading as decoding ability toward the written text quickly and accurately and understanding what is read, meanwhile, writing is as the ability to produce connected text (sentences, paragraphs, and documents), either by handwriting or keyboarding, that communicates an idea or information. According to Amalia (2017), reading is the appropriate input as the primary model which writing skill is learned. In other words, comprehending and composing skills are reinforced one another during reading and writing activities. It is clear that both reading and writing are closely related.

Reading is seen as an essential skill in daily life. People can see the world through reading. Novia, (2017) describes that reading is the window to the world, particularly when learning a foreign language. It is viewed that reading helps the learners to experience their mind in perceiving whatever happens around the world. Thousands of information used to add the learners' knowledge in learning a foreign language can be achieved through reading extensively the enormous versions of written sources or materials such as books, journals, newspapers, magazines, internetbased sources, etc. Without reading, the language learners cannot be able to have an improvement on their vocabulary mastery that is very needed in the process of comprehending/ understanding what is read. As supported by Liunokas (2016, p.115) stated that people can write easily and fluently because they read before they write.

Iftanti (2012, p.149) explains that reading habits throughout the text are how often, how much, and what students read. It describes that doing much reading activities can foster learners' ability to understand the meaning of the written materials. The more learners read, the broader ideas and information the 
learners will have. When students have a lot of information, they can express their idea by writing it on the paper routinely. As a result, students' ability in writing will be improved. Similarly, Linuwih \& Winardi (2020, p.38) stated that reading habit is regarded as the most influencing factor in writing since people usually find out new ideas, fact, information, knowledge and experience from reading activity. It can be said that the habit of reading will make it easier to understand the meaning and gain a lot of knowledge so that it has a good impact on writing.

Furthermore, a research done by Oriogu (2017) reveals that reading habit has a significant effect on the learners' academic performance. The learners who have a good reading habit can easily observe, analyze, and comprehend the input knowledge that they will get during their learning process. As a consequence, it will impact on the improvement on their academic achievement. Besides, reading habit may also help learners to enhance their skills in writing. Lee and Wong, (2017) elaborates the influence of students, reading habit on their writing skill. The students who have good reading habit show will produce their writings as well. It means that reading habits and writing skills have a close relationship in the learning process with the same goal of obtaining good results.

Based on the elaboration and the assumption above, this study aimed at investigating whether reading habit of the eighth graders at SMPN 6 Kayuagung was significantly correlated to their writing skills or not.

\section{METHODOLOGY}

A correlational research was held to find out if there was a relationship between reading habit writing skills of the students at SMPN 6 Kayuagung. Students' reading habit was determined as the independent variable (X) and their writing skills as the dependent variable (Y). Based on Cohen et al. (2018), correlational research involves collecting data to determine whether, and to what degree, a relationship exists between two or more quantifiable variables.

The population was the eigth grade students of SMPN 6 Kayuagung. The students were appropriate to be the population for the research as they had learned descriptive text in the previous semester. In other words, the students were eligible to be tested dealing with 
their ability in descriptive writing. The samples were then selected through the use of purposive sampling technique. According to Johnson and Christensen (2014, p.264), in purposive sampling, the characteristics of the population were specified and individuals who have those characteristics were then located by the researcher. The samples had fulfilled the following criteria; they should be taught by the same English teacher, and have mobile phone with a good signal to access the test and the questionnaire from google form. As a result, 124 students consisting of 60 male and 64 female students were selected as the sample.

A questionnaire adapted from (Khalisa, 2018, p.33-34) and a writing test were administered to the samples to obtain the data. The questionnaire containing twenty questions about reading habit was used to know the reading habits of the eighth graders at SMPN 6 Kayuagung. Meanwhile, the writing test was to measure their skills in writing descriptive text. Both instruments had been valid in terms of its content and reliable before being applied.

Furthermore, to analyze the data that were received from the questionnaire, an analysis using 'Likert
Scale' with 5 scoring indicators beginning from 'Strongly agree' to 'Strongly disagree' was done. Next, the students' writings were scored using writing rubric and categorized and ranked based on five classification of scores. Finally, Pearson Product Moment Correlation coefficient on SPSS 20 was used to prove the formulated hypotheses.

\section{RESULTS AND DISCUSSION}

The statistical analyses had been done toward the data obtained from two instruments (questionnaire and writing test). First, the result of questionnaire showed that the mean score of reading habit was 81.90 with the standard deviation of 4.980. From the result of analysis using Likert Scale toward the questionnaire, it could be seen that the frequency of students' responses to reading habit questionnaire, and the five levels of reading habit were all perceived by the students with different numbers; "high" as the least perceived level and "very high as the most perceived one. Most students (82.4\%) obtained very high reading habit category. Then, most students responded 'Strongly Agree' to the seventeen indicators in the questionnaire. See the following table. 
Table 1. Distribution of Student's Reading Habit Scores

\begin{tabular}{lccc}
\hline Category & Score & Frequency & Percentage \\
\hline Very High & $80-100$ & 102 & $82.4 \%$ \\
High & $60-79$ & 22 & $17.6 \%$ \\
Middle & $40-59$ & 0 & $0 \%$ \\
Low & $20-39$ & 0 & $0 \%$ \\
Very Low & $0-19$ & 0 & $0 \%$ \\
\hline Total & & 124 & $100 \%$ \\
\hline
\end{tabular}

At the same time, the writing test result presented that the mean of students' writing skill scores was 83.50 and classified into good category. Then, from the distribution of the students' writing skill, it could be seen that the students fulfilled the five categories of writing skill such as "Fairly Good" as the least obtained category and "Very Good" as the most obtained category. It revealed the fact that most students $(73.6 \%)$ were in good category. Table 2 provides the information of wrting scores completely.

Table 2. Distribution of Students' Writing Scores

\begin{tabular}{lcll}
\hline Category & $\begin{array}{l}\text { Score } \\
\text { Interval }\end{array}$ & $\begin{array}{l}\text { Num. of } \\
\text { Students }\end{array}$ & $\begin{array}{l}\text { Percent } \\
\text { age }\end{array}$ \\
\hline Very good & $90-100$ & 14 & $11.2 \%$ \\
Good & $80-89$ & 91 & $73.6 \%$ \\
Fairly good & $70-79$ & 19 & $15.2 \%$ \\
Poor & $60-69$ & 0 & $0 \%$ \\
Very poor & $0-59$ & 0 & $0 \%$ \\
\hline \multicolumn{2}{c}{ Total } & 124 & $100 \%$ \\
\hline
\end{tabular}

In addition, the statistical analysis was done by applying Pearson ProductMoment Coefficient Correlation to know if there was a correlation between reading habit and writing skill. From the findings, it was shown that r-obtained was 0.685 at the level of significance of $p$-value which was less than 0.05 . The value of r-obtained was bigger than r-table value (0.176). It proved both formulated hypotheses; null and alternative hypotheses. As the result, alternative hypothesis was confirmed, meanwhile the null hypothesis was refused. In other words, there was a significant correlation between students' reading habit and writing skill. The following table shows the result of statistical analysis.

Table 3. Correlation between Students' Reading Habit and Their Writing

\begin{tabular}{llll}
\hline & & $\begin{array}{l}\text { Reading } \\
\text { Habit }\end{array}$ & $\begin{array}{l}\text { Writing } \\
\text { Score }\end{array}$ \\
\hline Reading & Pearson & 1 & $.685^{* *}$ \\
Habit & Correlation & & .000 \\
& Sig. (2-tailed) & 124 & 124 \\
& $\mathrm{~N}$ & & \\
\hline Writing & Pearson & $.685^{* *}$ & 1 \\
Score & Correlation & .000 & \\
& Sig. (2-tailed) & 124 & 124 \\
& $\mathrm{~N}$ & & \\
\hline$* *$ Correlation is significant at the 0.01 level (2-tailed).
\end{tabular}

**. Correlation is significant at the 0.01 level (2-tailed).

Then, to know the correlation level between variable $\mathrm{X}$ and $\mathrm{Y}$, the table of correlation index below was checked.

Table 4. Index of Correlation

\begin{tabular}{ll}
\hline The $\boldsymbol{r}$ score scale & $\begin{array}{l}\text { Interpretation of } \boldsymbol{r} \\
\text { score }\end{array}$ \\
\hline $0.80-1.000$ & Very strong \\
$0.60-0.799$ & Strong \\
$0.40-0.599$ & Medium \\
$0.20-0.399$ & Low \\
$0.00-0.199$ & Very low \\
\hline
\end{tabular}

From the table above, it was shown that the correlation between reading habit and writing skill of the students was classified into strong 
correlation (0.60-0.799) of score. It could be interpreted that students' reading habit was strongly related to students' writing skill. The strong correlation could reveal that the students who had good reading habit could improve their skills in writing. The students who experienced in reading greatly impact on their writing skills improvement including skill of grammar and mechanics. This finding was in agreement with Yorina (2014) who found that there was a correlation between reading habit and each aspect of writing performance. It was described that student's reading habit was correlated to each aspect of writing performance namely grammar, mechanics and fluency.

Moreover, this finding was also in line with (Setyaningsih, 2012) who found that reading habit significantly affected the writing performance in terms of their achievement in vocabulary mastery, reading comprehension, and writing product. In addition, (Risman, Jufrizal, and Rozimela (2019) found that one of the factor that can affect student in teaching and learning process especially in writing is students' reading habit. In addition, the correlation between students' reading habit and their writing skill of the eighth graders at SMP Negeri 6 Kayuagung investigated in this study was successfully proved.

\section{CONCLUSION}

This study was purposed to find out if reading habit was correlated to writing skill of the eighth graders at SMPN 6 Kayuagung. Based on the findings, a significant correlation was found between both variables. Having checked the table of correlation index, it was known that the correlation was classified into strong correlation. It could be concluded that students who had high reading habit also had good writing skill. Vice versa, the students who had low reading habit also had bad writing skill. This proved that the high and low levels of reading habit were very closely related to students' success in writing skill. Then, it could be inferred that students' reading habit was an important aspect of achieving a good score in descriptive writing skill.

\section{REFERENCES}

Adi, I. N. S. M., Padmadewi, N. N., \& Ratminingsih, N. M. (2017). The effect of STAD upon students with different level of self-essteem toward 
reading comprehension of eleventh grade students of SMAN 1 Kediri

Tabanan in the academic year 2013/2014. International Journal of Language and Literature |, 1(3), 158166.

Amalia, K. (2017). The correlation between reading habit and writing achievement of undergraduate students of English Study Program of UIN Raden Fatah Palembang (pp. 179).

Chettri, K., \& Rout, S. K. (2013). Reading habits - an overview. IOSR Journal Of Humanities And Social Science, 14(6), 13-17. https://doi.org/10.9790/083701461317

Cohen, L., Manion, L., \& Morrison, K. (2018). Research methods in education. Routledge.

Hariyadi, P., Wennyta, \& Fitri, N. (2018). An analysis of students' ability in writing descriptive text at the tenth grade students of SMAN 11 Jambi academic year 2017/2018. Repository Universitas Islam Sultan Syarif Kasim, 2(2), 39-46.

Iftanti, E. (2012). A survey of the English reading habits of EFL students in Indonesia. TEFLIN Journal, 23(2),
149-164.

https://doi.org/10.15639/teflinjournal. v23i2/149-164

Johnson, R. B., \& Christensen, L. (2014). Educational research quantitative, qualitative, and mixed approaches fifth edition. SAGE Publications, Inc. https://doi.org/10.4324/97813510046 26-12

Kellogg, R. T. (2018). 23 professional writing expertise: The Cambridge handbook of expertise and expert performance. https://doi.org/https://doi.org/10.1017/ 9781316480748.023

Khalisa, N. (2018). The correlation between students' reading habit and their writing ability. Ar-Raniry Islamic University. http://dx.doi.org/10.1016/j.neuropsyc hologia.2015.07.010\%0Ahttp://dx.doi .org/10.1016/j.visres.2014.07.001\%0 Ahttps://doi.org/10.1016/j.humov.201 8.08.006\%0Ahttp://www.ncbi.nlm.nih .gov/pubmed/24582474\%0Ahttps://do i.org/10.1016/j.gaitpost.2018.12.007 \%0Ahttps:

Krashen, S. (2016). Compelling reading and problem-solving: The easy way (and the only way) to high levels of language, literacy and life 
competence. Epoch Making in English Language Teaching and Learning 8 .

Lee, J. Y. V., \& Wong, A. S. C. (2017). The relationship between leisure reading habits, vocabulary and writing of english language learners (ELLs). Language Education in Asia, 8(2), 195.

https://doi.org/10.5746/LEiA/17/V8/I 2/A03/Lee

Linda, S. (2018). Assessing student learning: A common sense guide. John Wiley \& Sons.

Linuwih, E. R., \& Winardi, Y. K. (2020). The influence of reading habit on students' writing skill. ANGLOSAXON: Jurnal Ilmiah Program Studi Pendidikan Bahasa Inggris, 11(1), 37. https://doi.org/10.33373/as.v11i1.243 2

Liunokas, Y. (2016). The contribution of reading activities. Ethical Lingua, 3(2), 114-121.

Miller, B., McCardle, P., \& Long, R. (2012). The reading-writing connection. In International Reading Association (pp. 53-68). https://doi.org/10.4324/97810030139 83-5
Muhyidin, A. (2020). Does the writing exposition text ability correlate to reading habit and discourse markers mastery? Journal for the Education of Gifted Young Scientists, 8(2), 885895. https://doi.org/10.17478/JEGYS.6820 65

Muis, N., Zainil, \& Radjab, D. (2013). Improving students' reading comprehension of descriptive texts by using pictures and semantic mapping at grade VII.1 of SMPN 2 X Koto Diatas Solok Regency. Journal English Languange Teaching (ELT), 1(2), 1-11.

Novia, F. (2017). Using Bamboo Dancing Method to improve reading skill. Language and Education Journal, 2(1).

http://ejournal.uniski.ac.id/index.php/ LEJ/article/view/55

Oriogu, C. D. (2017). Effect of reading habits on the academic performance of students: A case study of the students of Afe Babalola University, Ado-Ekiti, Ekiti State. Teacher Education and Curriculum Studies, 2(5), 74. https://doi.org/10.11648/j.tecs.201702 05.13 
Palani, K. K. (2012). Promoting reading habits and creating literate society. Journal of Arts, Science \& Commerce, III(2), 90-94.

Risman, K., Jufrizal, \& Rozimela, Y. (2019). The effect of collaborative writing and reading habit toward students' writing. 1st International Conference on Education, Social Sciences and Humanities (ICESSHum 2019) The, 335, 310-315. https://doi.org/10.2991/icesshum19.2019.50

Setyaningsih. (2012). The relationship among reading habit, vocabulary mastery, and reading comprehension achievement of the students of SMPN 3 Sungai Lilin. Unpublished: Sriwijaya University. Yorina. (2014). The correlation between reading habit and writing efficacy of English literature departement students of IAIN Sultan Thaha Saifuddin Jambi. Unpublished: Sriwijaya University. 